\title{
FINITE ELEMENT MODEL AND EXPERIMENTAL STUDIES ON RUBBER-CORD COMPOSITE
}

\author{
TRAN HuU NAM \\ Hanoi University of Technology
}

\begin{abstract}
The rubber-cord composite (CRC) which is created of rubber matrix reinforced with textile cords is used for many applications such as pneumatic membranes, automobile tires, pneumatic air-springs, hydraulic hoses and many others. The CRC is characterized by strongly anisotropic material behaviour and can simultaneously undergo large elastic deformations. In this paper a finite element $(\mathrm{FE})$ model was developed and applied to study the mechanical responses of CRC. This model consists of 8-node hexahedral brick elements describing rubber matrix and 3-D spar elemeits for modeling of textile cords. The experimental studies in uniaxial and cyclic tension were performed. The material constants of textile cords were fitted to experimentally measured data by approach technique using linear and bilinear elastic models. The simulations of uniaxial tensile tests using proposed $\mathrm{FE}$ model were carried out. The numerical results of simulations were compared to experimental ones in order to verify the accurateness of the FE model. The obtained results indicated that the proposed FE model can be applied for the modeling and simulation of mechanical behaviour of CRC.
\end{abstract}

Key words: FE model, rubber-cord composite, pneumatic air-spring

\section{INTRODUCTION}

Nowadays textile composites and inflatable structures are becoming increasingly popular for a variety of applications in many fields - civil engineering, architecture, vehicle and aerospace engineering. Typical examples include membrane roofs and covers, sails, inflatable buildings and pavilions, airships, inflatable furniture, airspace structures, air-springs etc, Air-springs form an example of layered multiphase flexible composite structures that consist of rubber matrix and stiff reinforcement made of textile cords. The high modulus, low elongation cords carry most of the load, and the low modulus, high elongation rubber matrix preserves the integrity of the composite and transfers the load. The primary objective of this type composite is to withstand large deformation and fatigue loading while providing high load carrying capacity.

The combination of CRCs is especially effective when the composite material needs to be strong in extension in the cord direction, but also needs to be flexible in the plane perpendicular to the cords (Pidaparti, 1997). This property is desirable in car tires because they need the strength in the cord direction to hold the air pressure, but will be flexible in order to provide a comfortable ride, and cut down on fatigue from bumpy roads. This property is also special necessary in pneumatic air-springs which are subjected to air pressure. They need the strength and flexibility in the radial direction.

Experimental data, although frequently found in the form of internal reports of companies, are poorly documented in the available literature. In order to overcome this problem, Reese (2000) has been set up a "computer testing device" to obtain appropriate stress 
strain data. The material parameters of the orthotropic continuum mechanical model will then be fitted to these "experimental" results. Due to the fact that the stiffness of the fibers is much higher than that of rubber some material constants have a much higher value than others. Therefore, it is important to fit certain groups of material parameters separately. The identification of material parameters of the models is often performed using classical homogeneous strain experiments (uniaxial extension or pure shear tests for example).

Motivated mainly by interest in the numerical simulation of hyperelastic materials are some orthotropic and transversely hyperelastic constitutive models have been proposed recently. Most of them are represented by strain energy function formulated as a polynomial (Bonet, 1998) or an exponential (Holzapfel et al, 2000) or logarithmic function of orthotropic (or transversely isotropic) strain invariants. The classical phenomenological constitutive equations for rubber-like solids, such as Mooney-Rivlin, Neo-Hookean (Beatty, 1987; Holzapfel et al, 2000; Guo, 2001) or Ogden models (Ogden, 2001) are progressively replaced by more physical models based on statistical considerations in various engineering applications.

More recently, a phenomenological constitutive model that is capable of predicting the large deformations of CRC has been presented by Nam (2006). The behaviour of the rubber matrix was described by Ogden model and the influence of the cords was embodied by the exponential function that was developed by Holzapfel et al. (2000). However, the development of the constitutive theory of anisotropic elastic or viscoelastic materials at finite strains is still far to be complete and the publications in this field are sparse.

Furthermore, the mechanical behaviour of $\mathrm{CRC}$ is also studied using FE model. Reese et al. (2001) was developed a model describing the inelastic material behaviour of pneumatic membranes reinforced with roven-woven textile and modeling FE for orthotropic material behaviour in the pneumatic membranes. Payer et al. (1997) presented a largescale three dimensional FE contact analysis of automobile tires. In the computational model a hybrid finite element is employed for describing the nearly incompressible behaviour of rubber and the reinforcing cords as represented numerically by means of rebar elements.

In this paper, a FE model is proposed for analysis of mechanical response of CRC. This model is created based on combining of 8-node hexahedral brick elements describing rubber matrix and 3-D spar elements for modeling of textile cords. The uniaxial and cyclic tensile tests are also performed on the different material samples. From experimental results, the material constants of textile cords were fitted by approach technique using linear and bilinear elastic models. After that proposed FE model is used like a "virtual" testing model as described by Reese (2001) for simulation of uniaxial tensile tests. Numerical results of simulations were compared to experimental ones in order to verify the accurateness of the FE model.

\section{MATERIAL STRUCTURE OF RUBBER-CORD COMPOSITE}

A CRC of cylindrical membrane of pneumatic air-spring (Fig. 1) that is made from the composite with rubber matrix reinforced by textile cords is investigated. This material is usually considered as an anisotropic hyperelastic material and made up of four layers the inner and the outer layer of calandered rubber and the two plies of reinforced textile 
cords (Fig. 2a). The angle of the two families of reinforced textile cords is approximately $76^{\circ}$ (Fig. 2b). The geometry of cross section of material sample is shown in Fig. 3. The total thickness of material samples is $2 \mathrm{~mm}$ in which the distance of two plies of textile cord is $0.6 \mathrm{~mm}$. The diameter of reinforced cords is $0.35 \mathrm{~mm}$ and the distance of two cords in the same layer is $0.5 \mathrm{~mm}$.
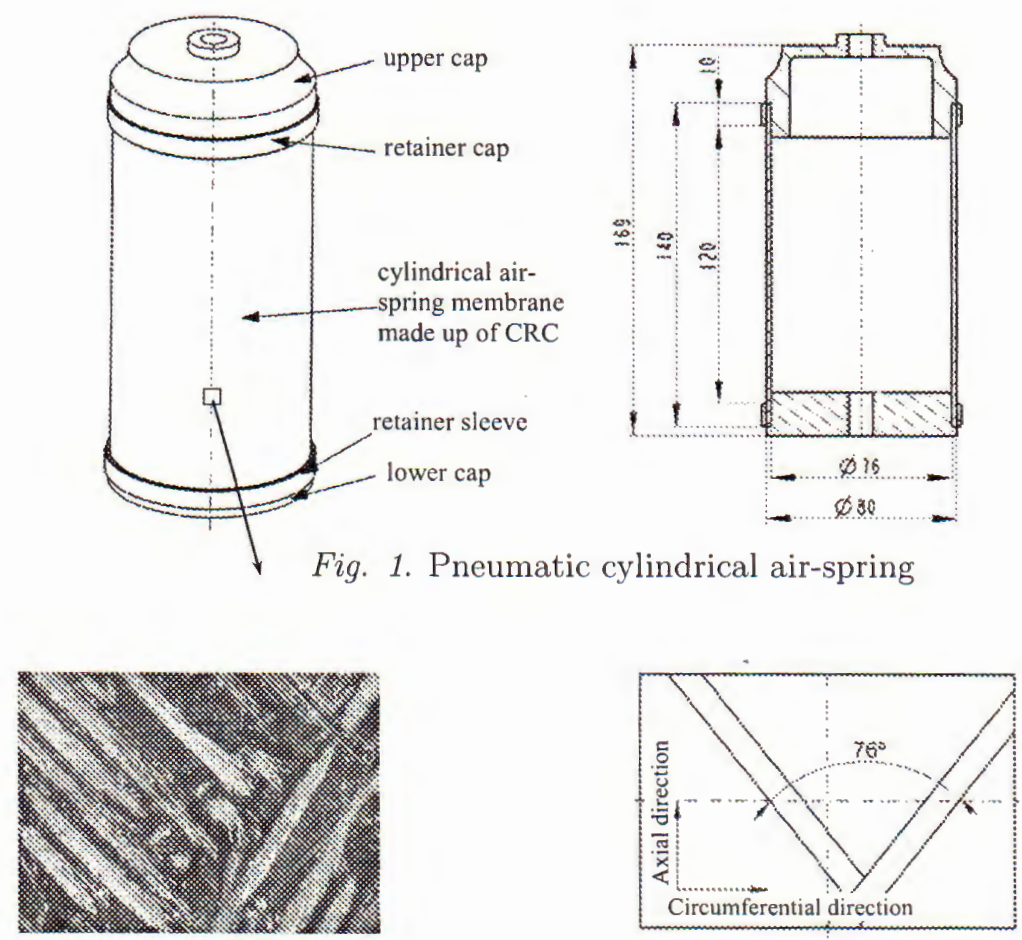

Fig. 2. Material structure of CRC
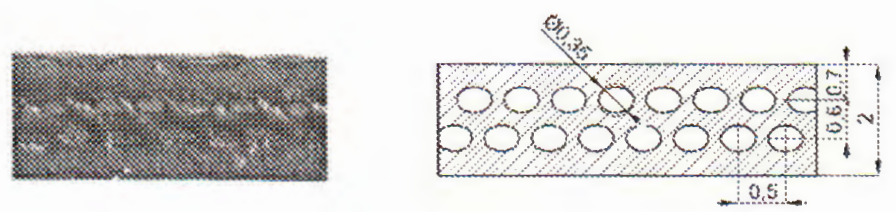

Fig. 3. The cross section of cord-rubber composite sample

\section{FINITE ELEMENT MODEL OF CRC}

As described above the CRC created from two phases, i.e. rubber matrix and reinforced textile cords. The behaviour of rubber matrix is considered as isotropic hyperelastic solid and textile cords as elastic solids. In present work the Ansys software is selected for modeling and FE analysis of the CRC. However, in Ansys there is not any material model which is appropriate for modeling of anisotropic hyperelastic material in general and CRC material in particular. Therefore a $\mathrm{FE}$ model for $\mathrm{CRC}$ is proposed containing two different element kinds in which the 8-node hexahedral brick elements (Solid 185) describing the 
rubber matrix and 3-D spar elements (Link 10) with red and green colors for modeling of elastic textile cords (Fig. 4). Note that 3-D spar element is only subjected tensile loading. The dimensions of 8-node brick element are defined based on the dimensions and position of spar elements as well as distance between them (see Fig. 2-3). Due to these reasons, the maximum available dimension of an element of $\mathrm{FE}$ model for the CRC is selected as $0.6 \times 0.6 \times 0.8 \mathrm{~mm}$ (Fig. 4)
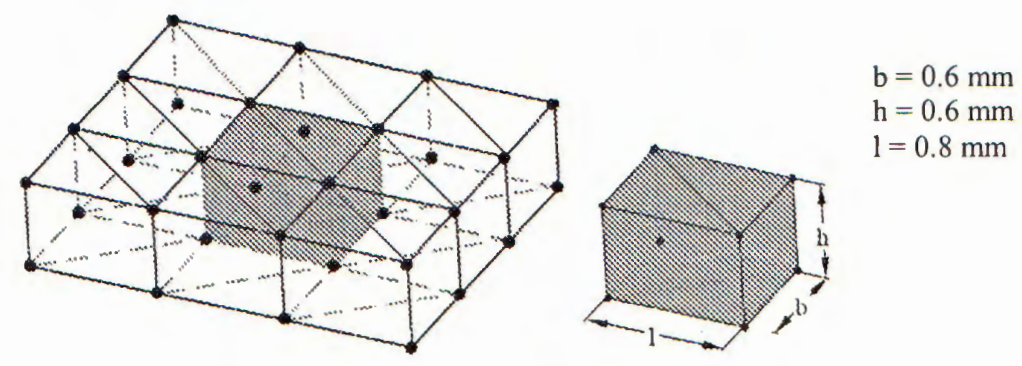

Fig. 4. Finite element model of CRC

The response of rubber matrix can be simulated using Mooney-Rivlin model. The strain energy function of Mooney-Rivlin model is as following (Beaty, 1987):

$$
\begin{aligned}
\Psi= & C_{10}\left(\bar{I}_{1}-3\right)+C_{01}\left(\bar{I}_{2}-3\right)+C_{11}\left(\bar{I}_{1}-3\right)\left(\bar{I}_{2}-3\right) \\
& +C_{20}\left(\bar{I}_{1}-3\right)^{2}+C_{02}\left(\bar{I}_{2}-3\right)^{2}+\frac{1}{d}(J-1)^{2},
\end{aligned}
$$

where $C_{10}, C_{01}, C_{11}, C_{20}, C_{02}, d$ are material parameters and $\bar{I}_{i}, i=1,2,3$ are modified invariants $J$ is the determinant of deformation gradient and is also the ratio of the deformed elastic volume over the undeformed volume of materials. The material parameters of Mooney-Rivlin for vulcanized rubber at room temperature (Aboudi, 2002) are used for numerical simulations as following:

$$
\begin{array}{lll}
C_{10}=0.2375 M P a, & C_{01}=0.2426 M P a, & C_{11}=-0.567 M P a \\
C_{20}=7.41 k P a, & C_{02}=0.0464 k P a, & d=1.0256 \mathrm{kPa}^{-1}
\end{array}
$$

The mechanical behaviour of textile cords is simulated using the constitutive equations of the linear and bilinear elastic models. The material constants of both material models of textile cords will be fitted to the experimental results by the method of least squares.

\section{EXPERIMENTAL STUDIES}

\subsection{Uniaxial tensile tests}

Tensile tests of different material samples of pneumatic cylindrical air-spring membrane were performed on the testing machine TiraTest 2000 with setting a force sensor in the range of $\pm 10 \mathrm{kN}$ at a loading rate of $20 \mathrm{~mm} / \mathrm{min}$ up to fracture of samples. The load was applied by a prescribed displacement at the top clamp. Tensile forces were recorded as a function of the displacement of the top clamp during testing. The elongations of samples segment between two white lines were measured using non-contacting laser extensometer installed combining with testing machine (Fig. 5). 


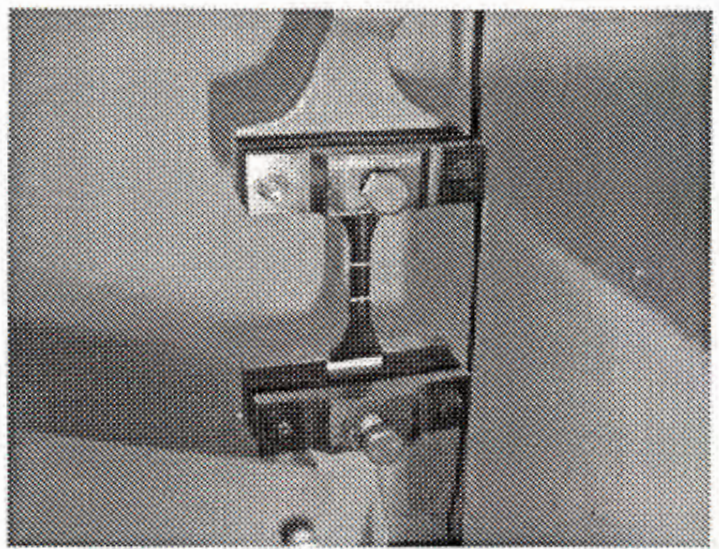

Fig. 5. The tensile test combining with installed laser extensometer

S-1
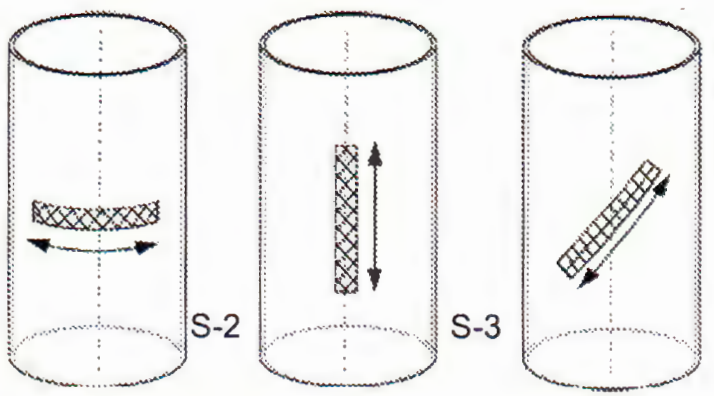

Fig. 6. The material samples in the three different directions

Three groups of material samples of pneumatic cylindrical air-spring membrane in three different directions were examined (Fig. 6). First group of the samples denoted $S-1$ was created in the direction of circumferential stress and the second one $(S-2)$ in the axial direction. The third group $(S-3)$ was made up in the direction of textile cords in order to determine the mechanical properties of cords. The dimensions of uniaxial tensile testing samples in $\mathrm{mm}$ are shown in Fig. 7. Testing samples have a uniform thickness of $2 \mathrm{~mm}$. The test samples have the band shape with dimensions of $10 \times 2 \times 115 \mathrm{~mm}$.

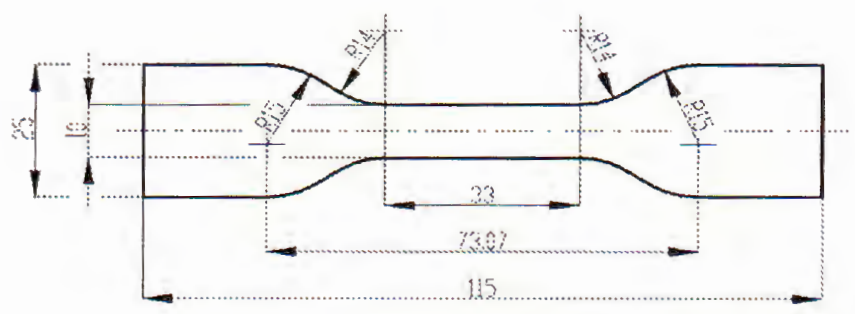

Fig. 7. Dimension of uniaxial tensile testing sample

The relative elongations of material samples captured from the laser extensometer and tensile forces until the fracture of samples were presented in table 1. Maximal relative elongation (up to 100\%) obtained in the sample of circumferential direction. 
Table 1. The testing data of material samples in three different directions

\begin{tabular}{|l|c|c|}
\hline Material samples & Maximal tensile forces & Relative elongations \\
\hline Circumferential direction (S-1) & $290 \mathrm{~N}$ & $105 \%$ \\
\hline Axial direction (S-2) & $440 \mathrm{~N}$ & $55 \%$ \\
\hline Direction of textile cord (S-3) & $1150 \mathrm{~N}$ & $22 \%$ \\
\hline
\end{tabular}

The force-elongation curves of uniaxial tensile tests until the fracture of three different material samples are shown in Fig. 8.

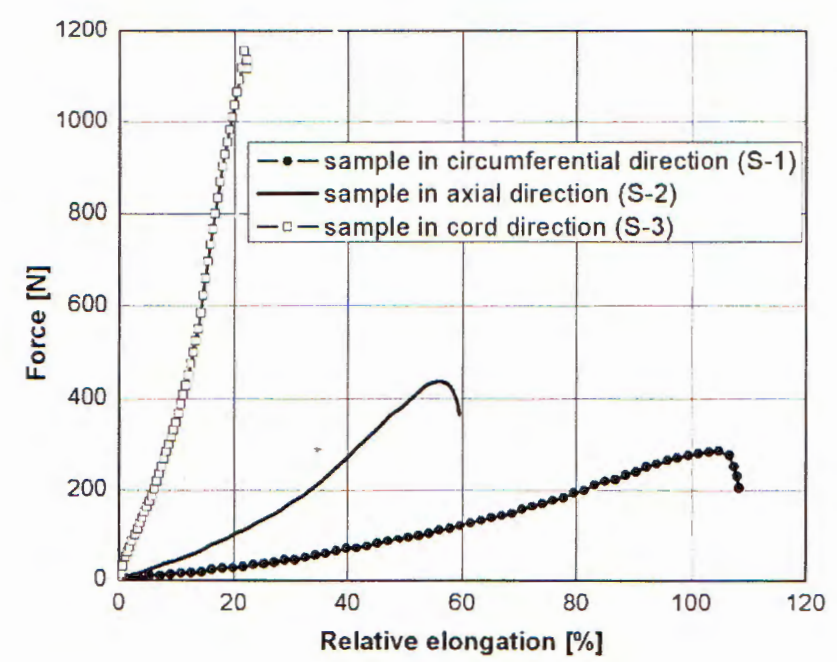

Fig. 8. Force-elongation curves of uniaxial tensile test until the fracture of samples

The characterization of rubber as well as rubber reinforced with textile cords is strongly influenced by of decreasing forces in the first cycles of loading. This property of rubber is known as Mullin's effect. Therefore the several pre-cycles of loading and unloading were applied on all material samples.

\subsection{Cyclic tensile tests}

Due to the Mullins effect and hysteresis the structural properties of elastomers change significantly during the first several times that the material experiences straining (Miller, 2000). The change in structural properties from cycle to cycle as measured by the stress strain function will diminish if an elastomer is loaded to a set strain level followed by complete unloading to zero stress several times. When the stress strain function no longer changes significantly, the material may be considered to be stable for strain levels below that particular set strain maximum. Furthermore a traditional stress-strain curve from a tensile test may not indicate that the material is not elastic unless the unloading behaviour is examined as well. Thus in order to determine the material parameters of rubber-cord composite it is recessary to perform the cyclic tensile tests. The raw data obtained from cyclic tests will be adjusted by isolating a stable cycle. This cycle then needs to be shifted such that the curve passes through the origin.

The determination of relative elongation until the fracture of samples in the uniaxial tensile test is necessary to execute the cyclic tensile tests. Based on testing data of uniaxial 
tensile tests shown in table 1 the cyclic tensile tests are carried out. The parameters used for cyclic tensile tests are shown in Table 2.

Table 2. The parameters used for cyclic tensile tests

\begin{tabular}{|c|c|c|c|c|}
\hline $\begin{array}{c}\text { Material } \\
\text { samples }\end{array}$ & $\begin{array}{c}\text { Loading rate } \\
(\mathrm{mm} / \mathrm{min})\end{array}$ & $\begin{array}{c}\text { Loading } \\
\text { cycles }\end{array}$ & $\begin{array}{c}\text { Relative } \\
\text { elongations }(\%)\end{array}$ & $\begin{array}{c}\text { Displacement of } \\
\text { top clamp (mm) }\end{array}$ \\
\hline S-1 & 5 & 5 & 88 & 40 \\
\hline S-2 & 5 & 5 & 34 & 15 \\
\hline S-3 & 5 & 5 & 20 & 15 \\
\hline
\end{tabular}
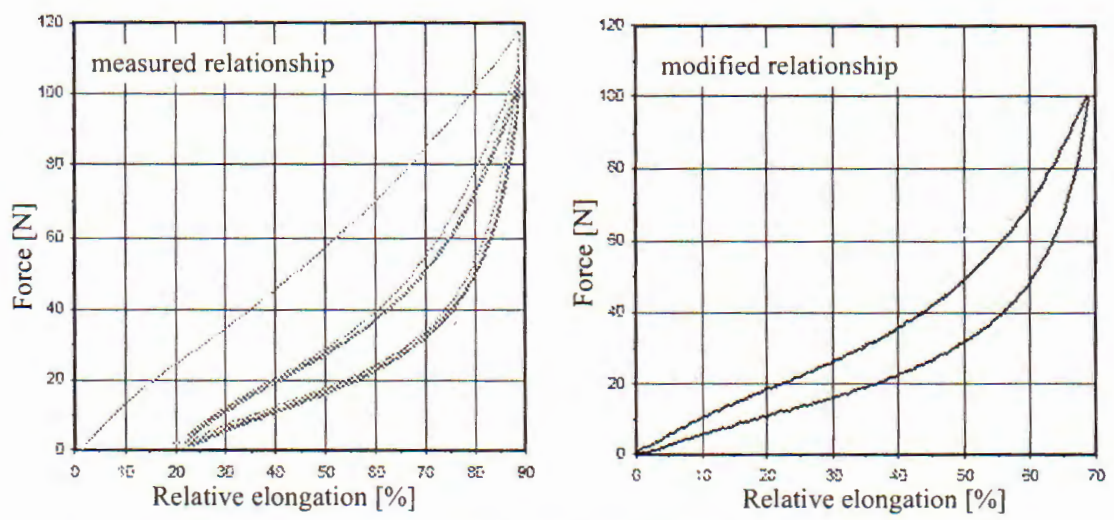

Fig. 9. Force-elongation relationship of sample S-1 in loading and unloading
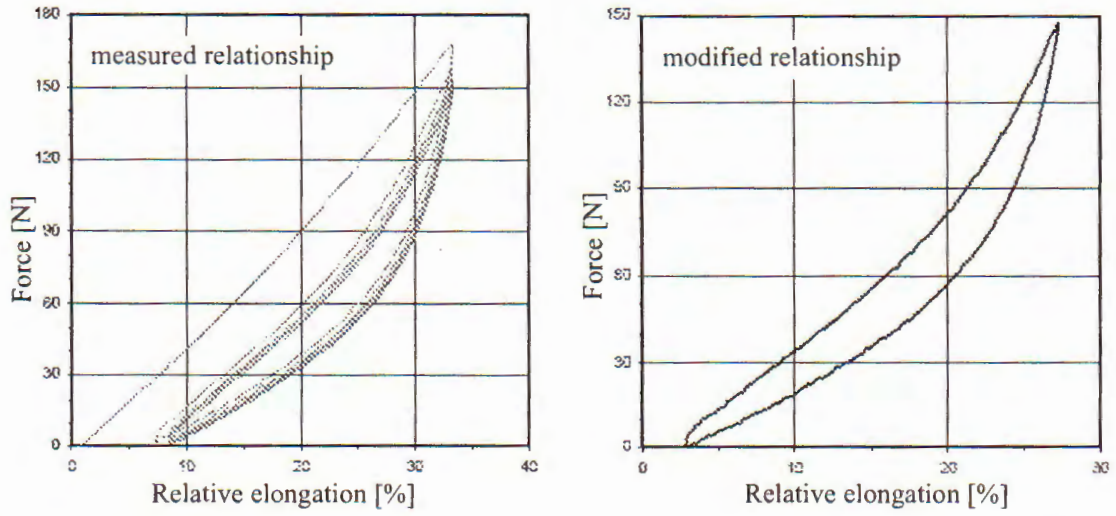

Fig. 10. Force-elongation relationship of sample S-2 in loading and unloading

The elongations were measured by means of non-contacting laser extensometer. The force-elongation relationships of material samples in three different directions in loading and unloading were shown in Fig. 9-11 during cyclic tensile tests.

However, in order to identify the material parameters of model from the experimental data, only one cycle is chosen. This cycle has to keep unchanging of mechanical properties of materials. For most elastomers, Miller (2000) shown that the stress strain function will 

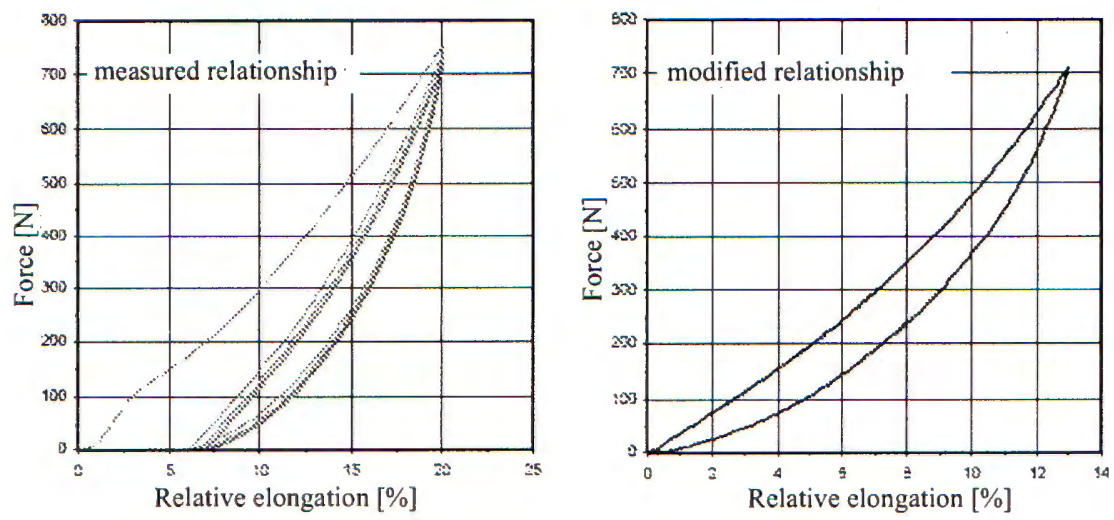

Fig. 11. Force-elongation relationship of sample S-3 in loading and unloading

be stable after between 3 and 20 repetitions. Since the fifth cycles of cyclic tensile tests were used for the identification of material parameters. The final curves are shown on the right side of Fig. 9 to Fig. 11. The entire stable cycle can be entered for the curve fit once shifted to zero force for zero elongation. Fitting a single cycle gives an average hyperelastic behaviour to the hysteresis in that cycle.

\section{IDENTIFICATION OF MATERIAL CONSTANTS}

The linear elastic model of cords is expressed by a constitutive equation:

$$
\sigma=E \varepsilon,
$$

where $\sigma=\frac{F}{A}$ is a stress and $\varepsilon=\frac{l-l_{0}}{l_{0}}$ is relative elongation (strain).

For linear elastic model, the material constant of textile cords is fitted to tensile testing result of material sample in the direction of textile cords using function (5.1) by the method of least squares.

The bilinear elastic model of textile cords is expressed by two different half-lines (Fig. 12), thus the constitutive equations using for fitting functions are following:

$$
\begin{gathered}
\sigma_{1}=E_{1} \varepsilon, \\
\sigma_{2}=E_{2} \varepsilon+b,
\end{gathered}
$$

where $b$ is constant term of equation (5.3)

Assuming that both the half-lines have a joint point with $\operatorname{strain} \varepsilon_{s}$, thus

$$
E_{1} \varepsilon_{s}=E_{2} \varepsilon_{s}+b \text {. }
$$

Now the measured points are divided into two groups, the first group refers to expression (5.2) with the condition of relative elongation $\varepsilon_{I} \leq \varepsilon_{s}$ and the other group to expression (5.3) with the condition of $\varepsilon_{I I}>\varepsilon_{s}$. The material constants of bilinear elastic model of textile cords are fitted to the experimental results by the method of least squares with additional condition (5.4).

The results of material constants of both models are presented in table 3 . The measured stress-elongation relationship in the cord direction and fitting lines of both models are shown in Fig. 12. 


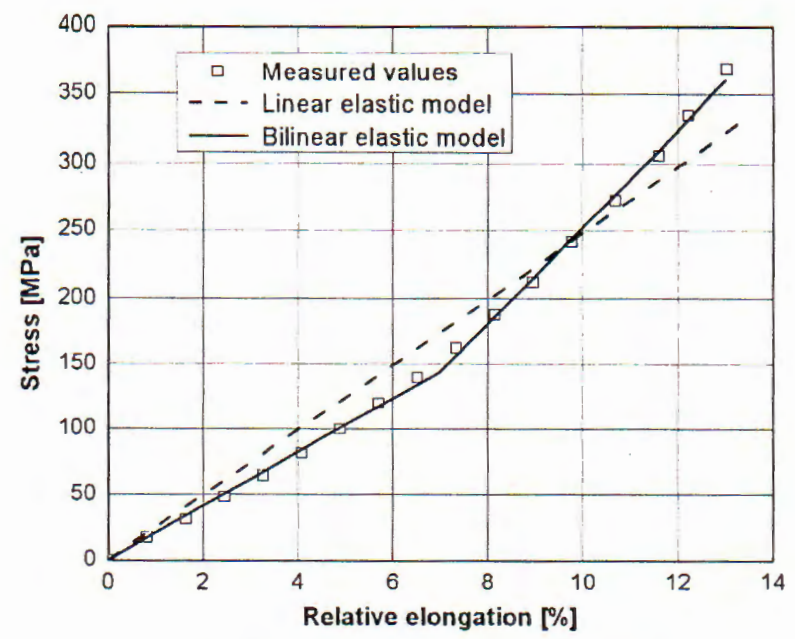

Fig. 12. Stress-elongation relationships

Table 3. The material constants of linear and bilinear elastic models of textile cords

\begin{tabular}{|c|c|}
\hline Linear elastic model & Bilinear elastic model \\
\hline $\mathrm{E}=2486 \mathrm{MPa}$ & $E_{1}=2070 \mathrm{MPa}, E_{2}=3580 \mathrm{MPa}$ \\
$\nu=0.35$ & $\nu=0.35, \quad \varepsilon_{s}=0.0694, \quad b=-75.924 \mathrm{MPa}$ \\
\hline
\end{tabular}

\section{NUMERICAL SIMULATION}

In this section the tensile tests on $\mathrm{CRC}$ are simulated in Ansys to verify proposed FE model above. Material samples of CRC are created in Ansys based on the FE model and using two kinds of elements. The element Solid 185 is used for modeling of rubber and Link 10 for textile cords. Mooney-Rivlin model (3.1) is adopted for modeling of rubber matrix and the linear elastic model (5.1) with material constants shown in the table 3 is applied for textile cords. The comparison between simulated and measured relationships of force-elongation was shown in Fig. 13. The simulated results shown that proposed FE model is appropriate for modeling of $\mathrm{CRC}$. The deformation of material sample in circumferential direction corresponding to the displacement clamp of $40 \mathrm{~mm}$ described in Fig. 14. The results in Fig. 14 indicated that the deformation of textile cords is much smaller than that of rubber matrix in comparison. It means that textile cords in CRC have very small elongation.

\section{CONCLUSIONS}

A CRC of cylindrical membrane of pneumatic air-spring was described as composite with rubber matrix reinforced by textile cords. A FE model was developed and applied to study the mechanical behaviour of CRC. This model consisted of 8-node hexahedral brick elements describing rubber matrix and 3-D spar elements for modeling of textile cords. The experimental studies on CRC were investigated in this paper. The data of uniaxial tensile and cyclic tensile tests were presented. The obtained results of uniaxial tensile tests until the fracture of material samples were used for execution of cyclic tensile tests. The material constants of textile cords in CRC were fitted to modified measured 

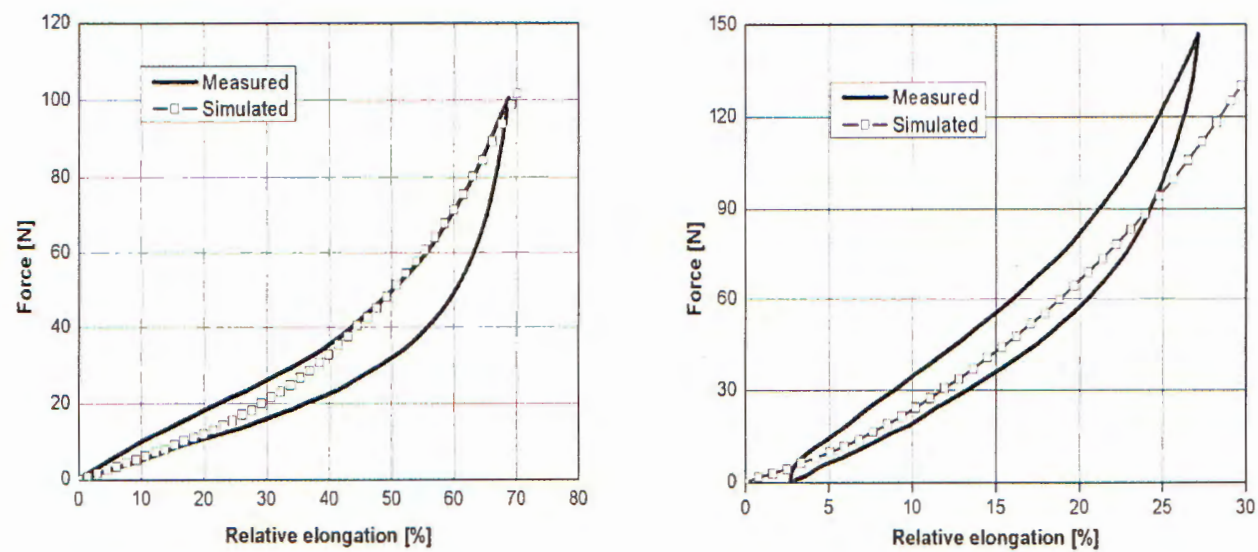

Fig. 13. Comparison of force-elongation relationships: (a) for S-1 and (b) for S-2

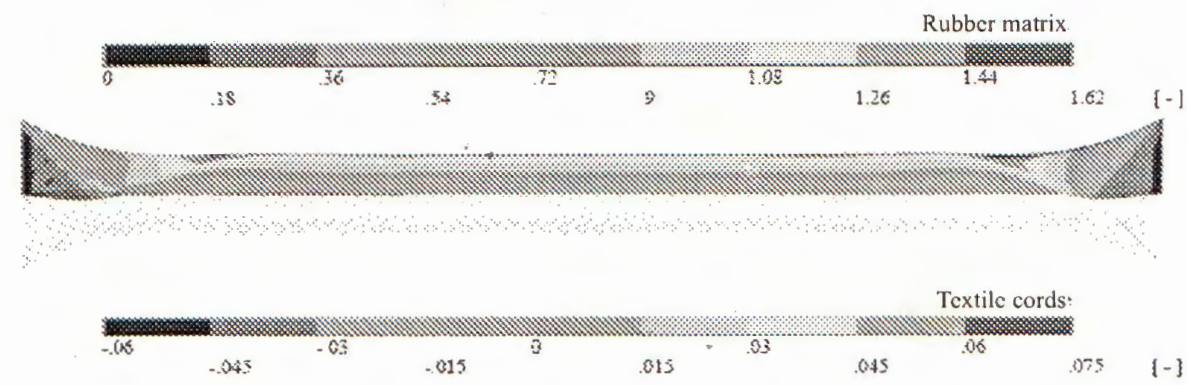

Fig. 14. Deformation of material sample S-1 with displacement of $40 \mathrm{~mm}$

data of cyclic tensile tests by approach technique using linear and bilinear elastic models. The experimental simulations in uniaxial tension were investigated using proposed FE model. The simulated results were compared with experimental ones in order to verify accurateness of the FE model. The obtained results show that proposed FE model is appropriate for the modeling and simulation of the mechanical response of CRC.

Acknowledgement. This publication is completed with financial support from the National Basic Research Program in Natural Science.

\section{REFERENCES}

1. J. Aboudi, Micromechanical analysis of the fully coupled finite thermoelastic response of rubber-like matrix composites, International Journal of Solids and Structures 39 (2002) 25872612.

2. M. F. Beatty , Topics in finite elasticity: Hyperelasticity of rubber, elastomers, and biological tissues with examples, Appl. Mech. Rev. 40 (12) (1987) 1699-1734.

3. J. Bonet,A. J. Burton, A simple orthotropic, transversely isotropic hyperelastic constitutive equation for large strain computations. Comput. Methods Appl. Mech. Engrg. 162 (1998) 151-164.

4. X. Guo, Large deformation analysis for a cylindrical hyperelastic membrane of rubber-like material under internal pressure, Rubber Chemistry and Technology 74 (2001) 100-115.

5. G. A. Holzapfel, T. C. Gasser, R. W. Ogden, A new constitutive framework for arterial wall mechanics and a comparative study of material models, Journal of Elasticity 61 (2000) 1-48. 
6. K. Miller, Testing Elastomers for Hyperelastic Material Models in Finite Element Analysis, Axel Products, 2000.

7. T. H. Nam, T. I. Thinh, Large deformation analysis of inflated air-spring shell made of rubbertextile cord composite, Structural Engineering and Mechanics: An International Journal 24 (1) (2006) 31-50.

8. R. W. Ogden, Background on Nonlinear Elasticity, Lemaitre J., ed., in the handbook of materials behaviour models, Academic Press, Boston, 75-83, 2001.

9. H. J. Payer, G. Meschke, H. A. Mang, Application of the finite element method to the analysis of automobile tires, Proc. of the IUTAM/IACM Symposium, June 2-6, Vienna, Austria, 1997.

10. R. M. V. Pidaparti, Analysis of cord-rubber composite laminates under combined tension and torsion loading, Int. J. of Composites Part B 28 (1997) 433-438.

11. S. Reese, Large Deformation FE Modeling of the Orthotropic Elastoplastic Material behaviour in Pneumatic Membranes, European Congress on Comput. Methods Appl. Mech. Engrg, Barcelona, 11-14 September, 2000.

12. S. Reese, T. Raible, P. Wriggers, Finite element modeling of orthotropic material behaviour in pneumatic membranes, International Journal of Solids and Structures 38 (2001) 9525-9544.

Received May 21, 2007

\section{MÔ HİNH PHẦN TƯ HŨU HÂN VÀ NHŨ'NG NGHIÊN CỨ THỤC NGHIẸM TRÊN VẠT LIỆU COMPOSITE NỀN CAO SU CỐT SỢI}

Vật liệu composite nền cao su cốt sợi được ứng dụng để tạo ra nhiều sán phẩm công nghiệp, chẳng hạn các màng khí nén, lốp ô tô, lò xo giản chấn khí nén, ống thủy lực và nhiều ứng dụng khác. Vật liệu này đặc trưng bởi ứng xử dị hướng và có thể tức thời chịu được biến dạng đàn hồi lớn. Trong bài báo này trình bày một mô hình dùng phần tử hữu hạn để mô phơng ứng xử cơ học của vật liệu composite nền cao su cốt sợi vải. Mô hình này bao gồm các phần tứ khối 8 nút 6 mặt mô tả nền cao su và các phần tử ba chiều chỉ chịu kéo mô tả ứng xứ của cốt sợi. Nhiều nghiên cứu thực nghiệm đã được tiến hành trên vật liệu này. Các thí nghiệm kéo một chiều, kéo theo chu kỳ đã được thực hiện. Những kết quả thí nghiệm kéo theo hướng cốt sợi được dùng để nhận dạng các hằng số vật liệu của sợi. Cuối cùng những mô phóng thực nghiệm dựa trên cơ sở mô hình phần tử hữu hạn đã trình bày để kiểm định độ chính xác của mô hình. Những kết quả mô phỏng được so sánh với các kết quả thí nghiệm đã chứng tỏ mô hình dùng các phần tứ hữu hạn đưa ra thích hợp để nghiên cứu ứng xử cơ học của vật liệu composite nền cao su cốt sợi. 